\title{
BIRTH \& RECONSTRUCTION OF EQUALITY IN THE UNITED STATES
}

\section{NASCIMENTO E RECONSTRUÇÃO DA IGUALDADE NOS ESTADOS UNIDOS}

\author{
Alexander Tsesis \\ Loyola University School of Law (Chicago, IL, USA) \\ Recebimento: 13 jan. 2020 \\ Aceitação: 26 jan. 2020
}

\begin{abstract}
Como citar este artigo / How to cite this article (informe a data atual de acesso / inform the current date of access):
TSESIS, Alexander. Birth \& reconstruction of equality in the United States. Revista da Faculdade de Direito UFPR, Curitiba, PR, Brasil, v. 64, n. 3, p. 75-106 set./dez. 2019. ISSN 2236-7284. Disponível em: $<$ https://revistas.ufpr.br/direito/article/view/72128>. Acesso em: 11 mar. 2020. DOI:
\end{abstract} http://dx.doi.org/10.5380/rfdufpr.v64i3.72128.

\begin{abstract}
The United States was born of a normative and political aspiration asserted in its declaration of independence. The document did not simply contain a list of reasons for ending colonialization, but established equality as key ideal which remained imbedded in the nation's ethos and is central for the U.S. representative democracy. Despite the normative statements of human rights, the status of the United States was deeply tainted because the framers of the Constitution retained protections for the institution of slavery. But many other legal and cultural anomalies also existed from the inception of nationhood, including the subjugation of women and the retention of propertied privileges as qualifications for voting and obtaining political offices. Amendments that were made to the Constitution after the Civil War (1861-1865) significantly advanced the rule of law but simultaneously required greater sincerity in abiding to the founding testament. Reconstruction in the United States was achieved through amendment of the original Constitution rather than the enactment of a new document. The ratification of the three new legal instruments, known as the Reconstruction Amendments, codified the Declaration's statement of rights and equality. Liberty alone was no answer to the problem of slavery. The post-Civil War amendments also prohibited the unequal treatment of persons and created new guarantees of the franchise. The judiciary, which was responsible for interpreting the new constitutional provisions, showed itself to be a conservative institution that reined in reconstruction and thereby diminished the effect of the new guarantees of equality.
\end{abstract}

\section{KEYWORDS}

Declaration of independence. Equality. Reconstruction. Judicial interference.

\section{RESUMO}

Os Estados Unidos nasceram de uma aspiração normativa e política afirmada em sua declaração de independência. O documento não continha apenas uma lista de razões para acabar com a colonialização, mas estabeleceu a igualdade como ideal fundamental, que permaneceu incorporado ao ethos da nação e é central para a democracia representativa americana. Apesar das declarações normativas de direitos humanos, o status dos Estados Unidos foi profundamente manchado porque os autores da Constituição mantiveram proteções ao instituto da escravidão. Mas muitas outras 
anomalias legais e culturais também existiram desde o início da nação, incluindo a subjugação das mulheres e a retenção de privilégios apropriados como qualificação para votar e obter cargos políticos. As emendas feitas à Constituição após a Guerra Civil (1861-1865) avançaram significativamente o estado de direito, mas simultaneamente exigiram maior sinceridade ao cumprir o testamento fundador. A reconstrução nos Estados Unidos foi alcançada por meio de emenda da Constituição original, em vez de promulgação de um novo documento. A ratificação dos três novos instrumentos legais, conhecidos como Emendas da Reconstrução, codificou a declaração de direitos e igualdade da Declaração. Só a liberdade não era resposta para o problema da escravidão. As emendas pós-Guerra Civil também proibiram o tratamento desigual de pessoas e criaram novas garantias quanto ao direito de voto. O judiciário, responsável por interpretar as novas disposições constitucionais, mostrou-se uma instituição conservadora que controlou a reconstrução e, com isso, diminuiu o efeito das novas garantias de igualdade.

\section{PALAVRAS-CHAVE}

Declaração de independência. Igualdade. Reconstrução. Interferência judicial.

\section{INTRODUCTION}

The United States was born of a normative and political aspiration asserted in its declaration of independence. The break from British sovereignty occurred on July 2, 1776. Two days later the Second Continental Congress immortalized the terms of national identity in a formal Declaration of Independence. The document did not simply contain a list of reasons for ending colonialization, as was the case with declarations of independence that emerged from the South American independence drive of the early nineteenth century. While the U.S. Supreme Court has never formally incorporated the Declaration, its mandates of equality remain imbedded in the nation's ethos and are at the foundation of U.S. representative democracy.

Despite the normative statements of human rights, the status of the United States was deeply tainted because the framers of the Constitution retained protections for the institution of slavery. The exploitation of African slaves weighed on the country's conscience from its beginnings. But many other legal and cultural anomalies also existed from the inception of nationhood, including the subjugation of women and the retention of propertied privileges as qualifications for voting and obtaining political offices.

Amendments that were made to the Constitution after the Civil War (1861-1865) significantly advanced the rule of law but simultaneously required greater sincerity in abiding tp the founding testament. Reconstruction in the United States was achieved through amendment of the original Constitution rather than the enactment of a new document. The ratification of the three new legal instruments, known as the Reconstruction Amendments, codified the Declaration's statement of rights and equality. The evolving quest to define the founding ideals did not end with the abolition 
of slavery. Liberty alone was no answer to so great an evil. The post-Civil War amendments also prohibited the unequal treatment of persons and created new guarantees of the franchise. The judiciary, which was responsible for interpreting the new constitutional provisions, showed itself to be a conservative institution that reined in reconstruction and thereby diminished the effect of the new guarantees of equality.

\section{THE AMERICAN REVOLUTION AND THE QUEST FOR LIBERTY}

The founding generation of Americans set the nation on a course of liberty. They presented the country's ideals in general statements based on natural rights philosophy. Revolutionaries regarded rights to be innate, not merely the products of positive law. The emerging political philosophy of the eighteenth century conceived the rights of the people to be equally possessed at birth and divinely granted. They were not endowed by man and therefore could not be "repealed or restrained by human law” and existed prior "to all early government.”1

Civil society was thought to be a system operated for the mutual improvements beneficial to all members of the polity. Enlightened jurists like Theophilus Parsons, a future member of the Massachusetts Supreme Court, envisioned civility in which

each individual parts with the power of controuling his natural alienable rights, only when the good of the whole requires it; he therefore has remaining, after entering into political society, all his unalienable natural rights, and a part also of his alienable natural rights, provided the good of the whole does not require the sacrifice of them. ${ }^{2}$

The measure of a government's authority was the consent of individuals to join a civil order that was committed to coequal rights for the common defense and self-improvement.

On their face, the revolutionary ideals prohibited infringement of others' equal rights and natural freedoms. This did not justify libertinism; to the contrary, the people's representatives were expected to pass laws that constrained individuals for the common good ${ }^{3}$. Even slaveholders of the day proclaimed their affinity for liberty even though their conduct contravened the country's avowed philosophy. Anti-slavery forces were only in their nascent state, barely organized in the late eighteenth century, but they were beginning to articulate condemnations, in written and oral forms,

\footnotetext{
${ }^{1}$ Result of the Convention of Delegates Holden at Ipswich..., in MEMOIR OF THEOPHILUS PARSONS 359,365 (Boston, 1861) (1778); John Adams, A Dissertation on the Canon \& Feudal Law, in 3 THE WoRKS OF JOHN ADAMS 447, 449 (Charles F. Adams ed., 1851) (1782); Hampden, THE AlARM (No. III) (Oct. 15, 1773).

${ }^{2}$ Result of the Convention of Delegates Holden at Ipswich in the County of Essex, in THEOPHILUS PARSONS, MEMOIR OF THEOPHILUS PARSONS 359, 367 (Boston, 1861) (1778).

${ }^{3}$ Spartanus, The Interest of America, New-HAmpshiRe GazeTte, June 15, 1776; John Locke, The SECOND TREATISE §54, in Two Treatises of Government 346 (Peter Laslett ed., Cambridge Univ. Press rev. ed.1965) (1690).
} 
against the county's failure to live up to its ideals. While the founding generation contravened the rights of blacks, women, and others, they established national principle to which later generations could later turn to end injustices that were tolerated at the time of independence.

Of all the pamphlets and documents drafted by revolutionaries, none was as elegant, pithy, and influential as the Declaration of Independence. It listed reasons for the break with the Mother Country and, more importantly, stated the moral reasons for creating a separate nation. The document contained an ethical theory for peoplehood borne of a joint aspiration to end tyranny and achieve justice.

While the framers of American independence embraced inborn equal liberty, they failed to condemn slavery and misogyny. The Continental Congress even eliminated a paragraph in Thomas Jefferson's draft against the international slave trade. The Declaration nevertheless contained principles that, in the words of one of the prominent leaders of early America, was "the political creed of the United States."4

Their wavering on principle did not diminish the significance the universal statements about the universalizability of liberal equality. The persistence in their culture of systematic inequality, toward blacks, native Americans, and women was glaringly inapposite with the vehement claim that civil law had to follow the "law of natural reason and equity." ${ }^{5}$ Civil rights, belonging to everyone, were "not to be rummaged for, among old parchments" but discovered in human nature .

The national thesis that government must protect personal equality and ability to enjoy liberty was incompatible with the lack of legal protection against the prevailing and overt racial and gender discrimination. Some writings on the state of nature even conceived of a human condition, prior to the creation of governments in which no one was superior to anyone else. Civil order was meant to aggregate human power to protect rights against the precarious forces of greed and selfishness ${ }^{7}$. Yet it was cynical to speak of creating a meritocracy to better preserve "equality to the most extensive degree," ${ }^{\prime}$ while closing off opportunities to education, political, ownership, and many other rights that were open to men with adequate wealthy. Without equal access to the privileges of

\footnotetext{
${ }^{4}$ Samuel Adams, To the Legislature of Massachusetts, in 4 THE Writings OF SAMUEL AdAMS 353, 357 (Jan. 17, 1794).

${ }^{5}$ Samuel Adams, The Rights of the Colonists (Report of the Committee of Correspondence to the Boston Town Meeting Nov. 20, 1772), available at http://www.constitution.org/bcp/right_col.htm.

${ }^{6}$ Alexander Hamilton, The FARMer Refuted 38 (1775).

7 JudAh CHAMPiOn, CHRistian AND Civil LiBERTy CONSIDERED \& RECOMMENDED 7 (1776); A Full Vindication, in 1 THE WORKS OF ALEXANDER HAMILTON 6 (Henry Cabot Lodge ed., 2d ed. 1904) (1774).

${ }^{8}$ Boston GAZETTE \& COUNTRY Journal (Jan. 21, 1771) (signed “Vindex”); VIRGINIA GAZETTE (Dixon \& Hunter) (June 8,1776 ) at 2 (signed at the next publication date, June 15, 1776, as "Philanthropos”); DAVID RAMSAY, AN ORATION ON ADVANTAGES OF AMERICAN INDEPENDENCE 3, 7 (1778).
} 
citizenship, most American inhabitants were barred from meaningfully engaging in the political, cultural, and social life.

The most glaring contradiction was in access to the voting booth. If there was one complaint that could summon up the colonists’ disaffection it was, “No Taxation without Representation.” Yet many Americans were disaffected, disfranchised, and paid taxes without being able to vote or run for public offices. Seven colonies-New Hampshire, Rhode Island, New York, New Jersey, Virginia, North Carolina, and Georgia-predicated suffrage on the possession of real estate, while the others also granted the vote to male taxpayers or those with a set minimum amount of personal property. Other groups, like women, juveniles, blacks, Native Americans, Jews, Catholics, and indentured servants were explicitly excluded from casting ballots ${ }^{9}$. The majority of the population either lacked a political voice or did not exercise it.

\section{CONTRADICTIONS IN THE EARLY REPUBLIC}

The ideals of the Declaration of Independence raised expectations that in the new republic the people's inalienable rights would be preserved for the betterment of their safety and happiness. There was a general consensus in the early years of independence that the exploitation of slave labor was despotic. Slavery had been a norm since the mid-seventeenth century, but the new talk of equality in the nation's constitutional documents made the institution aberrational from the terms of national compact. The stated justifications for waging revolution were incompatible with the exploitation of humans as chattel.

The very language colonists used to justify the violent struggle put British attempts to enforce commerce laws - including the Tea Act of 1773, the Boston Port Act of 1774, and the Massachusetts Government Act of 1774 - as forms of enslavement. Josiah Quincy, Jr., a prominent member of the Sons of Liberty, exclaimed "Britons are our oppressors-I speak it with shame-I speak it with indignation-we are slaves." ${ }^{10}$ A signer of the Declaration of Independence, Stephen Hopkins, equated the colonists' status of having to pay a tax without being able to participate in Parliamentary debates before its passage to "the miserable condition of slavery."11 There were some, such as John Allen, who opposed the British Acts while refusing to stay silent about African slavery made leaders mere "trifling patriots," and "pretended votaries of Freedom" who trampled upon the natural rights

\footnotetext{
${ }^{9}$ Clinton Rossiter, SEEDTIME OF THE REPUblic 19 (1953).

${ }^{10}$ QuinCy, JR., OBSERVATIONS ON THE ACT OF PARLIAMENT... 69 (1774).

${ }^{11}$ HOPKINS, THE RightS OF COLONIES EXAMINED 4 (1764).
} 
and privileges of Africans while putting on a "vain parade of being advocates of the liberties of mankind."12

Of course, it was people of African descent who experienced the most disproportionate deprivations. The complaints of white colonists were trifling compared to the ubiquitous intolerance they suffered. Most were unable to voice their concerns, in large part because as slaves they lived oppressed lives and those of them who were free found doors shut to their enjoyment of the privileges of citizenship. There were those who would not be cowed, those who acquired ample skills for protest. A group of Massachusetts blacks, petitioned the state legislature in 1777 to "be Restored to the Enjoyments of that which is the Natural Right of all men" lest "the Inhabitance of this States No longer [be] chargeable with the inconsistancey of acting themselves the part which they condemn and oppose in others.” In a separate petition, “A Son of Africa” condemned the hypocrisy of entering the fray with the British while remaining silent about the continuation of slavery of Africans whom God, "by the law of nature, gave everything [...] equally alike to everyman richly to enjoy."13 This was not an isolated case.

Groups of black petitioners were found throughout America, including those from New Hampshire who argued deductively that accepting the proposition that "freedom is an inherent right of the human species" entails that slavery is a detestable tyranny. Black petitioners from Massachusetts convinced a convention to adopt the resolution,

That we abhor the enslaving of any of the human race, and particularly of the negroes in this country, and that whenever there shall be a door opened, or opportunity present for anything to be done towards the emancipation of the negroes, we will use our influence and endeavor that such a thing may be brought about. ${ }^{14}$

Fewer references were made to the inequalities women experienced, but the argument was available for anyone willing to listen. Mary Wollstonecraft, who published what may be characterized as the first feminist declaration of independence, took revolutionaries to task for establishing society on the premise of equality while chaining "half of mankind" to gender subordination ${ }^{15}$. Abigail Adams cajoled her husband John Adams, one of the most prominent members of the Continental

\footnotetext{
12 JOHN AlLEN, THE WATCHMAN's AlARM TO LORD - - -H 27-28 (1774).

${ }^{13}$ Quoted in Thomas J. Davis, Emancipation Rhetoric, Natural Rights, and Revolutionary New England: A Note on Four Black Petitions in Massachusetts, 1773-1777, 62 NEW ENG. Q. 248, 262 (1989); PHILIP S. FONER, FrOM AFRICA TO THE EMERGENCE OF THE COTTON KINGDOM 303 (1975).

143 Collections of THE MASSACHUSETTS HistoricAl SOCIETy 432-33 (5th ser. 1877); Thomas J. Davis, Emancipation Rhetoric, Natural Rights, \& Revolutionary New England: A Note on Four Black Petitions in Massachusetts, 1773-1777, 62 NeW ENG. Q. 248, 255, 261 (1989); WiLliam LinCOlN, HistORY OF WORCESTER, MASSACHUSETTS 99 (1862).

${ }^{15}$ A VindiCATION OF THE RigHTS OF WOMAN 247 (1792); About Wollstonecraft see Introduction to Mary Wollstonecraft, ViNDICATION OF THE RigHTS OF WOMAN 7 (M. Broday ed., 1986); A BOOKSHELF OF OUR OWN: WORKS THAT CHANGED WOMEN's LiVES 16 (Deborah G. Felder ed., 2005).
} 
Congress and later President of the United States, that he and fellow delegates "remember the ladies" in working out details of political representation ${ }^{16}$. In response John simply wrote back that he found the request to be humorous ${ }^{17}$, despite his commitment to natural rights, which he evidently did not believe fully extended to females. With political offices closed to her, Abigail could do little more than voice her opinion to statesmen. Nor was this the only issue on her mind. She also wrote John to end slavery, which regarded to be "a most iniquitous scheme."18

A speaker at an 1800 Independence Day celebration held sentiments similar to Adams’s. Celebration of national separation from England, she argued, should not be a commemoration of military victory nor of sovereignty but "because the American people have calmly, and deliberately declared, that "all men are created EQUAL." If this phrase is understood to "embrace only half of mankind," she went on to say, it amounts to "only half systems, and will not more support the burden of humanity.” The Declaration taught principles for the sons and daughters to realize their equal competence for great attainments. So too, the "rights of sufferages [sic]" were of equal importance to men and women. She went on to also bemone the fate of Africans forced to migrate to the United States, "Ethiop! Suffering brother" and implored him to

curse us not-some of us have principles of justice and bowels of compassion [...] Africa! Africa! [...] Where we have excited murders, robberies, and burnings, that we might punish them in our won land with endless, hopeless slavery, on the victims of our subtilty [sic] and their innocent posterity-Declaration of Independence! Where art thou now?

While America had understood the Declaration to end British aristocracy, visionary Americans could readily see that the system would need to be reconstructed, staying true to principle but abandoning the substantial privileges of sex and race ${ }^{19}$.

The egalitarian understanding of the Revolution was not, however, the mainstream view. A speaker actually justified inequality as pragmatically justifiable, despite the Declaration of Independence's statement on liberal equality. William Hunter spoke at an 1801 Fourth of July celebration to defend the "utility and expediency" of not allowing blacks and women to vote. He patronizingly rationalized that women were excluded from the franchise because they were so “interesting, fascinating, with power to direct us" that once in politics they were likely to "engross a complete monopoly of power.” He also believed persons of African dissent should be prevented from

\footnotetext{
${ }^{16}$ Letter from Abigail Adams to John Adams, AdAms FAmily CorREspondenCE, Mar. 31, 1776 (L. H. Butterfield ed., 1963).

${ }^{17}$ Letter from John Adams to Abigail Adams, Id., Apr. 14, 1776.

${ }^{18}$ Letter from Abigail Adams to John Adams, Id., Sept. 22, 1774.

${ }^{19}$ [Written by a Lady], An Oration Delivered On THE FourTh DAY OF July 1800 4, 5, 11 (Springfield: Henry Brewer 1808).
} 
representative governance because they were "extremely dependent, extremely ignorant, extremely indigent, and fiercely barbarous." ${ }^{20}$ His statements ignored that federal and state legal systems prohibited women and blacks from gaining the training and participation necessary to engage in civics on an equal level.

\section{ABOLITIONIST INFLUENCE}

Statements about natural equality made during the Early Republic influenced the course of emancipation throughout New England and parts of the middle-Atlantic. But the early zeal for immediate or gradual liberation dissipated as slavery became entrenched. Contrary to the hopes of prominent revolutionaries like Benjamin Rush and John Jay, adoption of the Declaration's statement of universal rights did not lead to slavery’s immediate demise. The Bill of Rights’ protections against the deprivation of "life, liberty, or property, without due process of law", existed side-by-side with other sections of the Constitution, like the Three-fifths Clause, which countenanced human bondage. Only during the Reconstruction would the Declaration of Independence's ideals of equal inalienable rights become incorporated into the Constitution. Constitutional reformation of the mid-nineteenth century was influenced by earlier abolitionist efforts.

Gradual abolitionism began to spread during the American Revolution, when ideas of liberty and equality spread widely throughout the colonies. In the late eighteenth century abolitionist societies existed in states like Connecticut, Pennsylvania, Maryland, and New York. Authors condemned the institution heralding from North Carolina, Delaware, Rhode Island, and Maryland ${ }^{21}$. But it was only after the 1819 and 1820 debates on the Missouri Compromise that debate about the legitimacy of slavery took on national proportion. From that point, immediate abolitionists and gradualist anti-slavery authors set arguments later adopted by the post-Civil War Reconstruction Congress.

A full throated defense of equal human rights entered the U.S. Constitution in the mid-1860s, but the ideal developed in the pages of nineteenth century books and pamphlets that condemned slavery. In 1835, a leader of Unitarian anti-slavery efforts, made clear that the condemnation of the institution rested on the Declaration of Independence's defense of "the indestructible rights of every human being." Slavery stripped "man of the fundamental right to inquire into, consult, and seek his

\footnotetext{
${ }^{20}$ WiLliam HUNTER, AN ORATION, DELIVERED IN TRINITY CHURCH, IN NEWPORT ON THE FOURTH OF JULY, 1801, at 9-10 (1801).

${ }^{21}$ AleXAnder Tsesis, For Liberty And Equality: The LifE AND Times OF THE DeClaration Of INDEPENDENCE 5354 (2012).
} 
own happiness."22 In his 1839 book American Slavery as It Is Theodore Weld, an abolitionist with a national reputation, in and out of the halls of Congress, declaimed a breadth of issues the Reconstruction Congress would later confront. The evils he discussed included plunder of "bodies and minds, their time and liberty and earnings, their free speech and rights of conscience, their right to acquire knowledge, and property, and reputation.”23

A few visionary Northern congressmen also advocated this principled perspective. Many statements in Congress against the spread of slavery were made in the midst of debates about terms for territories seeking to enter the union as full fledged states. Senator Charles Sumner was among the foremost proponents of the view that federal power should extend to all territories and possessions of the United States. A representative statement appears during the Kansas/Nebraska debates on the terms of statehood. "Slavery," Sumner stated, "is an infraction of the immutable law of nature, and, as such, cannot be considered a natural incident to any sovereignty, especially in a country which has solemnly declared, in its Declaration of Independence, the inalienable right of all men to life, liberty, and the pursuit of happiness." 24 He not only spoke from the authority of natural law but also from the norm of the founding, national compact.

Abolitionists, whose writings and speeches influenced the framers of the Reconstruction Amendments, understood their efforts against slavery to be tied to the ethical values of independence. William Lloyd Garrison, the most important of all the immediate abolitionists, believed the end of slavery and women's equality to be implicit in the self-evident truths of the Declaration of Independence ${ }^{25}$. While Garrison thought of the pre-reconstructed constitution to be a compact born of hell ${ }^{26}$, other authors were more textual, for example linking abolition to the dictates of the General Welfare Clause ${ }^{27}$.

\section{RECONSTRUCTION IN THE UNITED STATES}

The Union victory in the U.S. Civil War did much more than alter the relationship between states and the federal government. It set in motion constitutional changes that overturned social

\footnotetext{
${ }^{22}$ William E. ChanNing, SLAVERY 47-48 (3d ed. 1835).

23 THEODORE D. WELD, AMERICAN SLAVERY As IT Is 7-8 (1839).

${ }^{24}$ CONG. GLOBE, 33d Cong., 1st Sess., app. 268 (1854).

${ }^{25}$ See William L. Garrison, An Address Delivered Before the Old Colony Anti-Slavery Society, At South SCITUATE, MASS. 17 (1839) ("[I]f we advocate gradual abolition, we shall perpetuate what we aim to destroy, and proclaim that the self-evident truths of the Declaration of Independence are self-evident lies.”).

263 WENDELL P. \& FRANCIS J. GARRISON, WILLIAM LLOYD GARRISON, 1805-1879, at 412 (1889).

${ }^{27}$ George W. F. Mellen, An Argument on the Unconstitutionality of Slavery 62 (1841); Charles Olcott, TWO LECTURES ON SLAVERY AND ABOLITION 88 (1838).
} 
hierarchies, ending oligarchical control of southern lands, through three Reconstruction Amendments: The Thirteenth Amendment was ratified in 1866, the Fourteenth Amendment in 1868, and the Fifteenth Amendment becoming part of the Constitution in 1870. In a short period, the United States had won a physical war against Confederate secession and an ethical war for freedom and liberty.

Congress had begun debating the Thirteenth Amendment even before hostilities had ended between the North and South. Many of speakers vehemently decried slavery and those customs and practices that discriminated against blacks. The language of the Thirteenth Amendment, which was ratified in December 1865, was particularly simple and, like the rest of the Constitution rather pithy: "Section 1 . Neither slavery nor involuntary servitude, except as a punishment for crime whereof the party shall have been duly convicted, shall exist in the United States, or any place subject to their jurisdiction. Sec. 2. Congress shall have power to enforce this article by appropriate legislation.” Congressmen who spoke in favor of the Amendment regarded its grand design to be far more than the literal text.

Missing from this wording was any mention of human equality. Charles Sumner had initially demanded addition of a clause providing that "all persons are equal before the law." 28 Its exclusion from the final version was not for lack of agreement with Sumner's sentiments. To the contrary, as Senator Jacob Howard believed, equality was built into constitutional abolition of slavery ${ }^{29}$. Congressman Isaac Arnold, a legislator with close connections to President Abraham Lincoln, asserted that Section 2 of the Amendment provided Congress the authority to pass laws guaranteeing that "equality before the law" would "be the great cornerstone" of American governance ${ }^{30}$.

Advocates of the Thirteenth Amendment thought of it not only as a reconstruction of the Constitution, but also a return to the founding ideals. In 1863, the year President Abraham Lincoln issued the Emancipation Proclamation, the National Convention of German Radicals announced their goals to "[a]bolition of slavery [...] [and r] evision of the Constitution in the spirit of the Declaration of Independence.”31 Similarly in Winter 1864, the Freedom Convention met in Louisville and expressed conviction that amending the Constitution was essential "to secure freedom to every person," in keeping with "the principles of freedom announced by the Declaration of Independence and the Federal Constitution." 32 A column in the abolitionist newspaper The Liberator, asserted that

\footnotetext{
${ }^{28}$ CONG. GLOBE, 38th Cong., 1st Sess. 521 (Feb. 8, 1864).

${ }^{29}$ CONG. GLOBE, 38th Cong., 1st Sess. 1488 (Apr. 8, 1864).

${ }^{30}$ Id. at 2989 (June 15, 1864).

31 The German Radical Convention, Cleveland Daily Herald, Oct. 24, 1863, at 3.

32 The Eastern News: To-day’s Dispatches, DAILY Evening Bull. (S.F.), Feb. 25, 1864, at 2.
} 
an amendment ending slavery "will give completeness and permanence to emancipation, and bring the Constitution into avowed harmony with the Declaration of Independence.”33

Similar sentiments were heard overseas. An attorney from Manchester, England wrote a friend in support of ratifying the constitutional amendment to abolish slavery: "Then will your first great Declaration of Independence become indeed a solid, enduring, noble reality, securing freedom as the birthright of all men.” He continued that returning to the nation's founding principles would help secure liberty as the human birthright to go hand-in-hand with "the precious heritage of liberty-equal rights and privileges of citizenship.”34 John Stuart Mill, the great utilitarian philosopher, wrote from England to encourage a friend to work toward ratification of the Amendment in order to "to break altogether the power of the slaveholding caste" and observe "the opening words of the Declaration of Independence.”35

Abolition wrought no small change in a country where slavery had flourished for more than two centuries. Not only did the Amendment end a far-reaching abuse of human rights. It also changed the federalist relationship between states and the national government by granting Congress much broadened powers over civil rights reforms. Congressman James F. Wilson of Iowa, chairman of the powerful House Judiciary Committee, emphasized how the Amendment fundamentally altered the structure of American government because it conferred Congress with the authority to pass laws even after slaves had been emancipated. Wilson understood that Section 2 granted Congress authority to pass laws to secure "human equality", whereby persons of all races would be "equals, before the law." 36 While the Amendment did not explicitly provide the right to vote, it was a necessary corollary to the advancement of political participation ${ }^{37}$.

In practical terms that seemed to mean that Congress could now realize the abolitionist ideal of protecting rights first identified in the Declaration of Independence. Senator James Harlan of Iowa, another confidant of the Lincoln family, believed national laws could now pass to prohibit discrimination against black service on juries, possession of property, and enjoyment of marriage ${ }^{38}$.

\footnotetext{
33 Universal Emancipation, Liberator (Bos.), May 6, 1864, at 1 (reprinting an extract from an April 8, 1864 speech delivered in the United States Senate by Senator Charles Sumner of Massachusetts).

${ }^{34}$ Letter from Thomas H. Barker to William Lloyd Garrison (Mar. 4, 1865), in Letter from Thomas H. Barker, Esq., LIBERATOR (Bos.), Mar. 31, 1865, at 50.

35 John Stuart Mill, BOS. DAILY ADVERTISER, June 8, 1865, at 2.

${ }^{36}$ Id. at 1319 (Mar. 28, 1864).

37 A Maryland representative to the House, speaking in Chicago, saw constitutional abolition to be a critical step in formulating a government under which "colored people” would have access to the ballot box and stated that "[t]hen all the principles of the Declaration of Independence will be executed; this government will rest on the rights of individual liberty and the right of every man to bear a share in the government of the country." Henry Winter Davis on Negro Suffrage, VT. WATCHMAN \& ST. J., July 14, 1865, at 2.

${ }^{38}$ Id. at 1439-40 (Apr. 6, 1864).
} 
Reconstruction for Harlan and fellow Radical Republicans heralded the nation's reawakening to its foundational potential, which had been squandered for the sake unity but at the expense of black liberty. Senator Henry Wilson of Massachusetts, who wrote a book condemning the grave subjugation of slavery, articulated the vision of the reconstructed Constitution that allowed obliteration of "the last lingering vestiges of the slave system; its chattelizing, degrading, and bloody codes; its dark, malignant, barbarizing spirit; all it was and is, everything connected with it or pertaining to it."39

Harlan and Wilson brought their abolitionist ideals to constitution-making. They and their fellow Radical Republicans in Congress relied on the Declaration of Independence and Preamble to the Constitution. With the passage of the Thirteenth Amendment they expected the foundational principles of American constitutional democracy to no longer be theoretical but practical. All races of man, they imagined, would henceforth be on an equal footing enjoying "that self-evident truth that [all men] are endowed by their creator with certain unalienable rights.”

Visionary congressmen who held influential political offices by the end of the Civil War and shortly thereafter planned to pass legislation pursuant to Section 2 for the furtherance of life, liberty, the pursuit of happiness, and betterment of the general welfare. They worked under the conviction that a true "state of freedom" included not simply an end to bondage but also the enjoyment of marital rights and the benefits of free labor. Putting an end to the badges and incidents of slavery and involuntary servitude not only benefitted persons of African descent but also "the seven millions of poor white people” whom "slavery [...] kept [...] in ignorance, in poverty and in degradation." ${ }^{40}$ New Hampshire Senator John Hale called on Americans to "wake up to the meaning of the sublime truths" that the country's “fathers uttered years ago and which have slumbered dead letters upon the pages of our Constitution, of our Declaration of Independence, and of our history." ${ }^{41}$ Others took a different tact, accusing “our ancestors” of hypocrisy for proclaiming the "inalienable right of liberty unto all men”, while refusing it to others ${ }^{42}$. In keeping with the view that Reconstruction was tied to the aspirations of independence, the Enforcement Clause was regarded to be legislative authority to pass civil rights law “to give practical effect to the principles of the Declaration of Independence."43

The Amendment authorized Congress to enforce laws against private and public injustices that are incidental to slavery or involuntary servitude. This was a substantial break with the extant

\footnotetext{
${ }^{39}$ Id. at 1324 (Mar. 28, 1864).

${ }^{40}$ Id. at 2990 (June 15, 1864) (Representative Ebon Intersoll); see also id. at 1324 (March 28, 1864) (Wilson); id. at 1199 (Mar. 19, 1864) (Wilson).

${ }^{41}$ CONG. GLOBE, 38th Cong., 1st Sess. 1443 (Apr. 6, 1864).

${ }^{42}$ Id. at 1461 (Apr. 7, 1864) (Senator John Henderson).

${ }^{43}$ Cong. GlOBE, 39th Cong., 1st Sess. 1159 (Mar. 2, 1866) (Representative William Windom).
} 
concept of federalism, which had left civil rights at the behest of the states. The Second Section of the Amendment provided the federal government greater deliberative and legislative powers over civil rights. While the principles remained those of the nation's founding, the Thirteenth Amendment reconstructed the form of government Americans had employed since the Revolution. The substantive rights enumerated by the Bill of Rights as well as unenumerated, natural rights, mentioned in the Ninth Amendment, became the boons of national citizenship, not subject to state infractions. The reason for this change was to achieve policy integrity commensurate with the ideal of individual rights being equally protected throughout the country. The benefits of this rebirth of revolutionary mandates included the rights to enjoy the rights to contract; sue; testify in court; and inherit, purchase, lease, hold and convey real property. This view overlapped with those of other, stated by Senator Harlan and Iowa Representative John A. Kasson, who believed the Thirteenth Amendment allowed Congress to pass laws against unfair restrictions on family, property, and judicial autonomy.

\section{AFTERMATH OF ABOLITION}

There were immediate signs of liberalization. A former slave, Charlotte Brown, spoke rapturously of the first Sunday of her emancipation. She recalled everyone "sittin' roun' restin' an' tryin' to think what freedom meant an' ev'ybody.” All of a sudden, an old woman started talking of the oppressions being lifted from those on the plantation. All of a sudden the former hands began to sing and dance in jubilation ${ }^{44}$. Schools sprang up with many freed people exploring opportunities for new vocations, Bible reading, literacy, and self improvement. Classrooms were open for children and adults. This development was a major break from oppression because prior to ratification of the Thirteenth Amendment, the only slave states that permitted educational instruction were Tennessee, Maryland, and Kentucky. In some states instructors could be imprisoned, fined, or whipped. Because of these oppressive regimes, only ten percent of southern black adults were literate in 1860 .

Benevolence societies and the U.S. Bureau of Refugees, Freedmen, and Abandoned Lands, better known as the Freedmen's Bureau, ran schools to eliminate illiteracy, one of the most devastating incidents of slavery. Federal involvement in education was a significant aspect of federal reconstruction because schools had previously been the exclusive province of states rather than national powers. To give a sense of the endeavor's scope, in North Carolina societies and religious organizations enrolled 11,826 students. In addition, the Freedmen’s Bureau operating in the state

\footnotetext{
${ }^{44}$ WeEVILS IN THE WhEAT: INTERVIEWS WITH VIRGINIA EX-SlAVES 58-59 (Perdue et al. eds., 1976).
} 
employed 439 teachers to educated about 20,000 pupils in 413 schools. In Alabama, the Bureau protected and helped transport northern teachers, pay for school construction, facility rental, and salary payments. Despite these positives, most schools were segregated ${ }^{45}$.

In response, local and roaming gangs attacked teachers and students in keeping with the concerted effort to retain centuries of inequality despite the dramatic changes to the Constitution. Moreover, some states enacted child apprenticeship laws, which bound children to employers for extended terms of service and thereby rendered education out of their reach. Judges reviewing challenges to these laws were authorized to evaluate the child's best interest, a subjective standard that allowed culturally imbedded racism to be determinative rather than a standard of fundamental rights ${ }^{46}$.

Even more oppressive than indenture law, which in 1867 the Bureau ordered revoked, were black codes. Shortly after ratification of the Thirteenth Amendment, plantation owners in the former slave states relied on these oppressive measures to continue oppressive labor practices despite the social reconstruction heralded by the Thirteenth Amendment. Among the most pernicious of blacks codes were requirements for adhesion contracts demanding black employees continue working as exploited labor for their former slaveholders, barring former slaves from seeking employment elsewhere. For example, Georgia required black "servants" who worked over a month for "masters" to sign binding agreements. Any worker who quit before the expiration of his employment contract forfeited all past wages and was subject to imprisonment and a \$500 fine. Another Georgia state law was of a different type: It granted employers the power to fire laborers without pay because of “disobedience [...] immorality, and want of respect.” Laborers could thus claim no job security, forcing many to subject themselves to effective indentured peonage in order to support families. The state of Mississippi subjected laborers to arrest and loss of wages for refusing to work for the duration

\footnotetext{
45 William Preston Vaughn, Schools for All: The Blacks \& Public EduCATiOn In the South, 1865-1877, at 1 (1974); ERIC FONER, RECONSTRUCTION: AMERICA's UNFINISHED REVOLUTION, 1863-1877, at 96 (Perennial Library 1989) (1988); Ivan E. McDougle, The Social Status of the Slave, 3 J. NEGRo HIST. 281, 289 (1918); Danger: An Educated Black Man, 22 J. BLACKS IN HIGHER EDUC. 19 (Winter, 1998-1999); Janet Cornelius, “We Slipped and Learned to Read": Slave Accounts of the Literacy Process, 1830-1865, 44 PHYLON 171, 176, 183 (1983); James A. Padgett, From Slavery to Prominence in North Carolina: Preparation, 22 J. NEGRo HIsT. 433, 435 (1937); John B. Myers, The Education of the Alabama Freedmen During Presidential Reconstruction, 1865-1867, 40 J. NEgRo EdUC. 163, 167 (1971); Sandra E. Small, The Yankee Schoolmarm in Freedmen's Schools: An Analysis of Attitudes, 45 J. S. HIST. 381, 381 (1979); Letter from Edmonia G. Highgate to M. E. Strieby, Dec. 17, 1866, in WE ARE Your Sisters: BLACK WOMEN IN THE NinETEENTH CENTURY 298-99 (Dorothy Sterling ed., 1984); KENNETH M. STAMPP, ThE ERA OF RECONSTRUCTION, 18651877, at 139 (1969).

46 James Hammond, Letter to an English Abolitionist, in THE IDEOLOGY OF SLAVERY 191-92 (1981); AVERY CRAVEN, RECONSTRUCTION: THE ENDING OF THE CIVIL WAR 119-20 (1969); Gilbert T. Stephenson, Racial Distinctions in Southern Law, 1 AM. Pol. SCI. REV. 44, 47-48 (1906); HERBERT G. GUTMAN, BlACK FAMILY IN SLAVERY \& FrEEDOM, 1750-1925, at 207-09 (1976).
} 
of the employment contract. Major General Hatch told the Congressional Joint Committee of Fifteen, investigating Southern postbellum behavior, that whites in Mississippi "wish to control the negro and his labor in such a way that he will be compelled to remain with them for never less than a year, and upon their own terms."47

In response to these draconian laws, Congress began using its enforcement power to pass laws to end de facto slavery. The existence of the 1865 amendment to the Constitution prevented states from claiming exclusive sovereignty over the liberties of its citizens. Radical Republicans understood the Amendment to have empowered them to end discriminations that impinged on fundamental rights and interfered with the general welfare; moderates, on the other hand, did not believe that the Thirteenth Amendment had gone that far, regarding reconstruction to have only extended to labor and property rights. Nevertheless thee was enough support in Congress to pass several reconstruction laws. The most important of these was the Civil Rights Act of 1866, which until this day remains in effect and used for real estate and contract discrimination. Other laws prohibited forced labor, punished slavery, and extended the federal judiciary's power to hear writs of habeas corpus ${ }^{48}$.

The 1866 Acts prohibition against public and private acts of discrimination in labor contracts was a radical departure from pre-bellum understanding of national unity. It advanced republican governance by extending federal government accountability to its citizens. Opening courts that had formerly been closed to black litigants, empowered individuals to use the federal courts to vindicate rights first announced in the Declaration of Independence. Reconstruction superseded discriminatory state tort, contract, and penal laws.

\section{CONTINUED RECONSTRUCTION OF FEDERALISM: FOURTEENTH AMENDMENT}

Several influential congressional leaders found that the Thirteenth Amendment's wording left doubt about the reach of congressional authority over civil rights. Contrary to the expectations of Senators Sumner and Howard, questions arose about whether it protected the equal rights and guaranteed the privileges and immunities of national citizenship. These ambiguities would be filled out by the Fourteenth Amendment, which is composed of several sections. The most important for

\footnotetext{
${ }^{47}$ Cong. GloBe, 39th Cong., 1st Sess. 111 (Dec. 21, 1865); W. E. B. Du Bois, Black ReCOnstruction 167 (KrausThomson Org. Ltd. 1973) (1935); David Oshinsky, Worse Than Slavery (1996); BENJAMIN B. KENDRICK, JOURNAL OF THE JOINT COMMITTEE OF FIFTEEN ON RECONSTRUCTION 274-75 (1914).

${ }^{48}$ Ch. 31, 14 Stat. 27 (1866) (Civil Rights Act of 1866); ch. 86, 14 Stat. 50 (1866) (Slave Kidnaping Act); ch. 187, 14 Stat. 546 (1867) (Peonage Act of 1867); ch. 27, 14 Stat. 385 (Act of February 5, 1867, expanding the scope of habeas corpus statutes).
} 
purposes of reconstruction and constitutional democracy were sections 1 and 5 , with the latter establishing substantive rights and the latter granting Congress enforcement power.

Section 1. All persons born or naturalized in the United States, and subject to the jurisdiction thereof, are citizens of the United States and of the State wherein they reside. No State shall make or enforce any law which shall abridge the privileges or immunities of citizens of the United States; nor shall any State deprive any person of life, liberty, or property, without due process of law; nor deny to any person within its jurisdiction the equal protection of the laws. $[\ldots]$

Section 5. The Congress shall have power to enforce, by appropriate legislation, the provisions of this article.

In the twentieth and twenty-first centuries, the first section of the Fourteenth Amendment would prove to be the most important to advancing women's rights, racial justice, educational equality, desegregation, and much more. But during the 1866 debates, congressmen tended to spend little time discussing the depth of its meaning. They had just finished extensive debates on the Civil Rights Act of 1866, and thought the broad principles annunciated about the statute, stemming to the nation's founding and moral development, applied to the second reconstruction amendment. That is not to say they were identical laws; indeed, the Act had not included explicit equal protection, privileges or immunities, and due process protections.

The original wording of the Section 1 of the Fourteenth Amendment granted affirmative legislative powers:

Congress shall have power to make all laws which shall be necessary and proper to secure to the citizens of each State all privileges and immunities of citizens in the several States, and to all persons in the several States equal protection in the rights of life, liberty, and property.

However, the final version, which is now part of the official Amendment, altered that sentence to

No State shall make or enforce any law which shall abridge the privileges or immunities of citizens of the United States; nor shall any State deprive any person of life, liberty, or property, without due process of law; nor deny to any person within its jurisdiction the equal protection of the laws.

This sentence contains principles on fundamental rights that were first set out in the Declaration of Independence, about equality by birth and rights to life and liberty, but the Supreme Court later interpreted the negative wording of these clauses to be a restriction grant of legislative, enforcement authority ${ }^{49}$. The justices aligned themselves with those statesman who had sought minimum change to state-federal government relations.

\footnotetext{
${ }^{49}$ City of Boerne v. Flores, 521 U.S. 507, 520, 532 (1997).
} 
The originally worded first section of the Fourteenth Amendment would have been an even more significant break with historic federalism and would have further nationalized civil rights. But this drastic a change to the relationship between states and the national government ruffled some congressmen's feathers. Conservative legislators worried that the proposed amendment would greatly change the "entire structure of Government."50 Their chief complaint was the reorientation of power between states and federal governments, which they were concerned could lead to centralized despotism. Opponents feared this would put people's liberties at danger because they would be forced to petition politicians at the national seat of government rather than their state representatives ${ }^{51}$. During debates on the Fourteenth Amendment, some Congressmen expressed concern that such a change to the Constitution would empower Congress to override all state laws about ordinary contracts, torts, and criminal punishment ${ }^{52}$. These concerns favored structural modifications but not radical change.

Opponents of the proposal that would have clarified the extent of congressional plenary power over civil rights argued to preserve state dominance in that area of law. They demonstrated willful ignorance about how much states’ rights orientation had facilitated the incidents, badges, and inequalities of slavery. The original Constitution permitted states to secure their citizens' and visitors' rights to slavery and discrimination.

A new direction was needed with the cataclysm of the Civil War fresh in the people's memories. This should have allowed the federal government to protect the equal liberties of all American people. Indeed, even in its ratified form, the Fourteenth Amendment had enormous potential to make fundamental rights invulnerable to states' intrigues. Among the greatest victories of the Civil War was the national consensus for social change, including constitutional protections of universal rights. Moderates won out, to have a negatively formulated amendment, rather than the Fourteenth Amendment's original affirmative wording. But there was still much hope and will among national legislators.

Arguing in favor of ratification was a radical congressman from Vermont. He spoke against the old-time complacency with the state of inequality so common throughout the states, despite their inconsistency with the ideals of the nation's founding:

\footnotetext{
${ }^{50}$ CONG. GLOBE, 39th Cong., 1st Sess. 2079-81 (Apr. 21, 1866).

${ }^{51}$ Id. at App. at 133 (Feb. 26, 1866)

${ }^{52}$ See for example the statement of Representative Robert Hale, who had abstained from voting for the Civil Rights Act but later helped override President' Johnson's veto of it. He expressed concern that the Fourteenth Amendment as it was originally proposed affected "all State legislation, in its codes of civil and criminal jurisprudence and procedure, affecting the individual citizen, may be overridden [...] and the law of Congress established instead.” Id. at 1063-64 (Feb. 27, 1866).
} 


\begin{abstract}
What is the object of the proposed amendment? It merely gives the power to Congress to enact those laws which will give to a citizen of the United States the natural rights which necessarily pertain to citizenship. It is intended to enable Congress by its enactments when necessary to give to a citizen of the United States, in whatever State he may be, those privileges and immunities which are guarantied to him under the Constitution of the United States. It is intended to enable Congress to give all citizens the inalienable rights of life and liberty, and to every citizen in whatever State he may be that protection to his property which is extended to the other citizens of the State. ${ }^{53}$
\end{abstract}

Despite this sentiment, the sponsors of the Fourteenth Amendment feared they did not have the two-thirds supermajority needed to pass the Amendment. Therefore, consideration of the initial, positively worded proposal was postponed and never revived ${ }^{54}$.

In its place, the Committee of Fifteen, which had been designated to formulate a draft of the Fourteenth Amendment, expressed the negative formulation of the Amendment's current form. Using the "No state shall..." language assuaged the concerns of Congressmen, providing crucial votes, but created a provision that narrowed the original and was less visionary about the potential reach of reconstruction. A long-lasting effect of the negative formulation was also greater empowerment of the judiciary to second-guess whether Congress acted against actual state violations.

Compelling testimony about the southern state recalcitrance to fulfill the demanding standards of the Thirteenth Amendment revealed a plethora of state violations. The worst of these were black codes designed to keep blacks in de facto bondage even after abolition. But other severe infractions were criminal behaviors that states did not prosecute. A Freedmen's Bureau Agent observed that

of the thousand cases of murder, robbery, and maltreatment of freedmen that have come before me, and of the very many cases of similar treatment of Union citizens in North Carolina, I have never yet known a single case in which the local authorities or police or citizens made any attempt or exhibited any inclination to redress any of these wrongs or to protect such persons. ${ }^{55}$

In these circumstances federal statutes would have provided avenues for redress, where state remedies were unavailable or subject to racialist under-enforcement.

Arguments in support of the Fourteenth Amendment asserted it would fulfill the promises of liberty of the original U.S. compact. In a speech before the House, Representative Shelby M. Cullom declared support of the Amendment because it would achieve those "self-evident" truths "our fathers" included in the Declaration and the Constitution, which in concert set down the "paramount

\footnotetext{
${ }^{53}$ Id. at 1088 (Woodbridge) (Feb. 28, 1866).

${ }^{54}$ Id. at 1095 (Feb. 28, 1866) (postponement).

${ }^{55}$ Laurent B. Frantz, Congressional Power to Enforce the Fourteenth Amendment Against Private Acts, 73 YALE L.J. 1353, 1355 (1964) (quoting Freedmen’s Bureau Agent).
} 
objects of government”: “[u]nion, justice, domestic tranquility, the general welfare, the securement of the blessings of liberty to themselves and their posterity."56 Representative George F. Miller of Pennsylvania thought it unfathomable to refuse support for Section 1's prohibition against the deprivation of life, liberty, or property without due process of law because those principles are "so clearly within the spirit of the Declaration of Independence."57 The sentiment that linked reconstruction to the birth of the nation were also shared by some officials in state governments. Indiana Lieutenant Governor Conrad Baker rallied an audience to ratify the Fourteenth Amendment to secure the equal enjoyment of natural rights,

which are defined [...] by our own Declaration of Independence, to be the right to life, liberty and the pursuit of happiness. And it is just because the rebels in the South and their allies in the North, destroy these natural and absolute rights of men by State legislation that this amendment has become a necessity. ${ }^{58}$

While the Fourteenth Amendment was a new direction for the country, it was directed at achieving and fulfilling of those commitments that were originally announced in the Declaration of Independence.

A dramatic change to the antebellum system of federalism appeared in the fifth section of the Fourteenth Amendment. It granted Congress the power to enact new laws against unequal treatment of persons based on arbitrary racial criteria. In those heady days of reconstruction, the Reconstruction Congress envisioned using enforcement authority to end racial segregation, violence, and employment practices.

\section{PUTTING THE BRAKES ON WOMEN'S SUFFRAGE}

This rosy picture should be tempered because of language in the Fourteenth Amendment that deviated from the universal principle of liberal equality for the common good. Section 2 contained the first use of "male" in the Constitution, which signaled a protection for men that was unavailable for women. The provision penalized states for excluding from voter rolls male inhabitants twenty-one year and older but created no penalty for the exclusion of women voters. That clause prohibited local officials from excluding black males from the franchise, but its use of "male"

\footnotetext{
${ }^{56}$ Cong. GLOBE, 39th Cong., 1st Sess. App. at 253 (June 16, 1866).

${ }^{57}$ CONG. GLOBE, 39th Cong., 1st Sess. 2510 (May 9, 1866).

${ }^{58}$ A Great Union Meeting of Daviess and Knox Counties, at Wheatland-- Speech of Lieutenant Governor Baker on the First Section of the Constitutional Amendment--It Does Not Confer the Right of Suffrage, InDIANAPOLIS DAILY J., Aug. 15,1866 , at 2 .
} 
maintained the federal policy of not interfering with states disenfranchisement of women. It granted states the sole discretion of whether to discriminate against women based on sex.

Long-committed abolitionists demanded that with Union victory discrimination against blacks and women end. For years the abolitionist movement had coupled the struggle for racial equality with the battle to secure women the right to vote. They regarded franchise to be essential for the empowerment of women. By providing half the human race no protection against overt exclusion from participation in representative government, even the Reconstruction Congress failed to live up to the universal ideals of the Declaration of Independence and Preamble to the U.S. Constitution. Moreover, it was a charade to think that all blacks would enjoy the status of equal citizenship when half of that population remained unable to vote ${ }^{59}$. Without the vote, half the nation remained in the despotic grip of a class system that was not based on wealth but on gender ${ }^{60}$. Only a groundswell of effort could end the aristocracy of sex. In the words of an 1879 petitioner to the California Congress supporting a state suffrage amendment, until "we feel the shackles loosen and give way [...] We are weary of sitting in the cellar of the temple of Liberty and listening to the distressing noise of the feet of our brothers overhead." ${ }^{1}$ Women suffrage had long been a rallying cry among abolitionists as a feature of every citizens' hereditary entitlement.

Feminists, led by advocates like Susan B. Anthony and Elizabeth Cady Stanton, had petitioned Congress to add a provision to the Fourteenth Amendment that would have guaranteed women the right to vote. At that stage of history, suffrage was denied to them throughout all the states and federal territories. ${ }^{62}$ Ten thousand signatures were gathered against adding "male" to the Constitution. Anthony complained that women had been "left outside" the political tent "with lunatics, idiots and criminals.”63

The Reconstruction Congresses and most abolitionists believed that anti-black discrimination needed to be tackled prior to addressing sex-based political discrimination. They regarded racial intolerance to be the greater of the two evils. Most thought of the period immediately

\footnotetext{
${ }^{59}$ Writing sardonically about limiting Section 2 to discrimination against males Elizabeth Cady Stanton rhetorically asked, “Do you believe the African race is composed entirely of males?” Letter from Stanton to Phillips, May 25, 1865, in 2 Elizabeth Cady Stanton as Revealed in Her Letters, Diary \& Reminiscences 104-05 (Theodore Stanton \& Harriot Stanton Blatch eds., 1922).

${ }^{60}$ National Woman Suffrage Association, Declaration of Rights for Women... 1876, in A CONCISE HISTORY OF WOMAN SufFRAGE 302 (Mary Jo \& Paul Buhle eds., 1978).

${ }^{61}$ WOMAN's JOURNAL, Dec. 6, 1879, at 388.

622 History OF WOMAN SufFrAGE, 1861-1876, at 91-92 (Elizabeth Cady Stanton, Susan B. Anthony \& Matilda Joslyn Gage eds., photo. reprint 1985) (1881).

${ }^{63}$ William L. O’Neill, Everyone WAs Brave: A History of FEMinism in AMERiCA 17 (1971).
} 
following the Civil War to be the "Negro's Hour."64 It was blacks who had suffered from the most appalling failures to live up to the nation's founding value of liberal equality for the common good.

In effect, at conventions such as those of the American Anti-Slavery Society in 1865 and Equal Rights Association in 1869, women's concerns were given a back seat to black rights, rather than tackling both simultaneously. Stanton and Anthony rejected the notion that they would need to put their trust in men while they waited for some future date for achieving the nation's commitment to equality. For them and their many followers, requiring women to trust their well-being to the predilections of an all male electorate was like trusting the British to care for the colonists' interests. Stanton explained this anomaly to the New York State legislature: "The noble cannot make laws for the peasant, the slaveholder for the slave; neither can man make and execute just laws for woman, because in each case, the one in power fails to apply the immutable principles of right to any grade but his own." 65 Her perspective expands on the nation’s nascent demand not to be taxed without first participating in the legislative process ${ }^{66}$. Woman's right to vote was commensurate with her enjoyment "equal personal rights and equal political privileges with all other citizens.”67

After failing to convince the nation to include women's suffrage in the Fourteenth Amendment, in 1869 Representative George Julian proposed an additional change to the Constitution that would end discrimination against women's ability to cast ballots ${ }^{68}$. But it would take until 1920 for the United States to ratify the Nineteenth Amendment, prohibiting voter discrimination based on sex.

\section{ENDING OVERTLY RACIAL VOTING CRITERIA}

Congress stuck to its decision to proceed at first with racial discrimination. Long before it began in earnest to debate granting women the right to vote and even before women began receiving the franchise in Western states, Republicans championed blacks right to vote. Many of them believed

\footnotetext{
${ }^{64}$ American Anti-Slavery Society, NATIONAL ANTI-SLAVERY STANDARD, May 13, 1865, at 2 (speech of the abolitionist Wendell Phillips).

${ }^{65}$ Quoted in Gretchen Ritter, Jury Service and Women's Citizenship before and after the Nineteenth Amendment, 20 L. \& HIST. REV. 479, 495 (2002).

661 GeORge Brown Tindall, AmericA: A NARRAtive History 176, 193 (1984) ("In a flood of colonial pamphlets, speeches, and resolutions, debate on the Stamp Tax turned mainly on the point expressed in a slogan familiar to all Americans: ' no taxation without representation,' a cry that had been raised years before in response to the Molasses Act of 1733.”).

672 HisTORY OF WOMAN SUFFRAGE, 1861-1876, at 349-50 (1881).

68 Julian’s proposal may be found at CONG. GLOBE, 41st Cong., 1st Sess. 72 (Mar. 15, 1869) and H.R.J. RES., 15, 41st Cong. 41 (Mar. 15, 1869). Text of the proposed amendment at EDWARD MCPHERSON, PolitiCAL MANUAL FOR 1869, at 506 (1869).
} 
this to be the crowning achievement of Reconstruction. They regarded the ability to vote to be intrinsic to securing fundamental rights as a whole because politicians would need the ingratiate themselves to black and white constituents. As Congress crafted the language of the future Fifteenth Amendment in 1869, it could only imagine the decades of struggle that lay ahead that would be required to end centuries of racial, political oppression.

While the motives for ending racial discrimination at the ballot box were partly pragmatic, with Republicans hoping to secure the black vote to stave off Democratic Party victory in the South, in large part the reasons for its passage were born of the impulse to achieve equality, which had moved revolutionaries and abolitionists to pursue political rights. The future president James Garfield eloquently explained, "I believe that the right to vote, if it be not indeed one of the natural rights of all men, is so necessary to the protection of their natural rights as to be indispensable, and therefore equal to natural rights.”69 The Amendment was also necessary for northern black voters. Between 1865 and 1869, six of eight referenda failed in norther states ${ }^{70}$. Modification of the national constitution was essential to reconstruct the representative democracy that the nation had promised in its Declaration of Independence but failed to fully implement.

Ratification of the Fifteenth Amendment significantly increased the number of eligible voters. Supporters of local autonomy, who had sought to keep blacks away from the polls even after abolition, were much weakened. The Amendment prohibited the use of three exclusionary criteria: race, color, and prior condition of servitude. Despite this crowning achievement, even this final amendment of the Reconstruction Era would fail to be the rebirth of freedom for which many had hoped. It lacked any prohibition against states' uses of property and literacy as qualifications for voting. This was not an unforeseen consequence with some Senators warning during debates that these criteria could undermine the very purpose of the amendment ${ }^{71}$. As they predicted, in the decades to come, the South would rely on neutral sounding laws to keep blacks from voting and running for elective offices. The Fifteenth Amendment turned out to be relatively easy to undermine through literacy tests.

\footnotetext{
69 James Baine, James Garfield et al., Ought the Negro to be Disfranchised? Ought He to Have Been Enfranchised?, 128 NoRTH AM. REV. 225, 225-26, 244-47 (1879).

${ }^{70}$ LaWanda \& John H. Cox, Negro Suffrage \& Republican Politics: The Problem of Motivation in Reconstruction Historiography, 33 J. S. HisT. 303, 318-320, 327-30 (1967).

${ }^{71}$ Cong. Globe, 40th Cong. 3d Sess. 861-62 (Feb. 4, 1869) (Senators Willard Warner); id. at 863 (Feb. 4, 1869) (Senator Oliver P. Morton); id. at 1626-27 (Feb. 26, 1869) (Senator Henry Wilson Wilson).
} 


\section{JUDICIAL INTERFERENCE}

Early judicial opinions appeared to align with the rebirth of freedom. The earliest interpretation of congressional reconstruction amendments came in United States v. Rhodes. The specific matter before Supreme Court Justice Noah Swayne, who was presiding over the case as designated circuit court justice, was Congress's power to pass the Civil Rights Act of 1866 . The case arose from a burglary committed by a white defendant against a black victim, Nancy Talbot. Typically, the criminal case would have been brought in a state court, but in this circumstances Kentucky law prohibited blacks from testifying against whites.

In dictum to the case, Justice Swayne asserted that if Congress lacked power to pass laws empowering federal courts to hear such matters than the reconstruction hopes and aspirations for equality would be nullity, “[S]imple abolition [...] would have been a phantom of delusion.” The Thirteenth Amendment, as he understood, had significantly altered the original Constitution, granting Congress with the authority to prohibit criminal discrimination ${ }^{72}$.

The majority of the Supreme Court, however, had significantly more conservative views about federalism. In the decades that followed the ratification of the Reconstruction Amendments, the Court curtailed congressional authority over civil rights. The Justices were set on diminishing federal jurisdiction, even in extreme cases where state laws prevented blacks from testifying against whites $^{73}$. The Court narrowly interpreted the Civil Rights Act of 1866's provision providing a right to access federal district courts when a state court discriminated against black litigants, countenancing crimes to be committed against blacks with equanimity ${ }^{74}$.

The most harmful opinion to Reconstruction is known as The Civil Rights Cases of 1883, which to this day continues to plague Congress's legislative power over civil rights laws ${ }^{75}$. The case brought for alleged violations of the Civil Rights Act of 1875, which prohibited segregation in public places of accommodation. Congress passed the law; therefore, it was binding throughout the country. The opinion significantly handicapped congressional enforcement power under Section 2 of the Thirteenth and Section 5 of the Fourteenth Amendments.

The Court held the Fourteenth Amendment only allowed Congress to pass laws against public not private acts of discrimination; Congress therefore lacked authority to pass the 1875 statutes

\footnotetext{
${ }^{72}$ United States v. Rhodes, 27 F. Cas. 785, 786, 793-94 (C.C.D. Ky. 1866).

${ }^{73}$ Blyew v. United States, 80 U.S. 581, 590-95 (1871) (holding that black witnesses to a murder could not testify in federal court under the Civil Rights Act of 1866, but only the victim of the murder, making any testimony impossible upon commission of a homicide).

${ }^{74}$ Civil Rights Act of 1866, ch. 31, §1, 14 Stat. 27, 27.

${ }^{75}$ United States v. Morrison, 529 U.S. 598, 602 (2000); City of Boerne v. Flores, 521 U.S. 507, 524 (1997).
} 
regulating commercial businesses. The federal government could no longer enforce the law. This set off a fever of discriminatory laws in the supposedly-reconstructed South, where the notion was farfetched that states, without national intervention, would render segregation illegal. Rather than look to the nation's founding principles, the Supreme Court rested its reasoning on a commonly accepted dichotomy of civil and social rights. Sumner had earlier complained that this rhetorical tool had been exploited against the actualization of equal rights and the continued separation of the races ${ }^{76}$. The majority relied on pre-Civil War notions of federalism to upend the reconstructed constitutional assurances of nationally recognized equal rights.

The lone dissent to the case was one of the most eloquent jurisprudential statements in U.S. history. Written by Justice John Marshall Harlan it echoed founding, abolitionist, and Radical Republican sentiments. He argued that the Fourteenth Amendment allowed for the regulation of states, businesses, and individuals. Furthermore, excluding blacks from participation in publically available activities was also an incident of slavery that the Thirteenth Amendment was meant to abolish.

The Civil Rights Cases had far reaching consequences. Later decisions, most notoriously Plessy v. Ferguson, recognized states right to segregate. Rather than uphold the ideals of national sovereignty for and by the people, the Court's nineteenth century, narrow interpretations of the Reconstruction Amendments favored racial elitism opting for a Social Darwinistic notion of success rather than granting the national government the authority to achieve the equal liberty promised at the nation's birth.

\section{CONCLUSION}

The founding principle of the United States was grafted into its Declaration of Independence and Preamble to the Constitution. It required government to preserve the people right to life, liberty, and the pursuit of happiness. The nation's founding documents asserted that people are born with equal unalienable rights. Government is established to advance the general welfare and to seek the people’s safety and happiness.

From the first years of the republic, however, the country failed to live up to its ideals. Racial and gender discriminations were mainstays of law and custom. Progressive voices called on the nation

\footnotetext{
${ }^{76}$ Cong. GLOBE, 42d Cong., 2d Sess. 382-83 (1872).
} 
to return to the aspirations of its birth, but the quest for hegemonic power kept authority in the hands of an elite defined by the color of its skin and by its sex.

The cataclysmic events of the Civil War brought about the possibility of change. It was then that minority voices calling for an end to hypocrisy gained the reins of national power. They passed three constitutional amendments. One ended slavery, another provided safeguards for equal rights and due process, and a third secured voting rights. Each granted Congress the power to govern expansively, to pass necessary and proper laws rationally related to constitutional democracy. But the late-nineteenth century Supreme Court of the United States thwarted that effort by narrowly construing the Reconstruction Amendments and thereby emasculating national, legislative authority. After the Court found the Civil Rights Act of 1875 to be unconstitutional, it took Congress until the 1960s to pass meaningful civil rights laws and the Supreme Court to uphold them, heralding a rebirth of civil rights.

\section{REFERENCES}

A GREAT Union Meeting of Daviess and Knox Counties, at Wheatland - Speech of Lieutenant Governor Baker on the First Section of the Constitutional Amendment - It Does Not Confer the Right of Suffrage. Indianapolis Daily J., Indianapolis, Aug. 15, 1866.

ADAMS, Abigail. Letter from Abigail Adams to John Adams, 22 September 1774. In: BUTTERFIELD, L. H. (ed.). Adams Family Correspondence. V. 1. Cambridge, MA: Belknap Press, 1963.

ADAMS, Abigail. Letter from Abigail Adams to John Adams, 31 March 1776. In: BUTTERFIELD, L. H. (ed.). Adams Family Correspondence. V. 1. Cambridge, MA: Belknap Press, 1963.

ADAMS, John. A Dissertation on the Canon \& Feudal Law. In: ADAMS, Charles F. (ed.). The Works of John Adams. V. III. Boston: Little and Brown, 1851 [Original: 1782].

ADAMS, John. Letter from John Adams to Abigail Adams, 14 April 1776. In: BUTTERFIELD, L. H. (ed.). Adams Family Correspondence. V. 1. Cambridge, MA: Belknap Press, 1963.

ADAMS, Samuel. The Rights of the Colonists. Report of the Committee of Correspondence to the Boston Town Meeting, Nov. 20, 1772. Available at: http://bit.ly/3bpHkDL. Accessed: 29 Jan. 2020.

ADAMS, Samuel. To the Legislature of Massachusetts. In: ADAMS, Samuel. The Writings of Samuel Adams: 1778-1802. V. 4. New York: Octagon Books, 1968.

ALLEN, John. The Watchman's Alarm to Lord N---H. Salem, MA: E. Russel, 1774.

AN ORATION Delivered on the Fourth Day of July 1800. By a Citizen of the United States. 
Springfield, MA: Henry Brewer, 1808.

BARKER, Thomas H. [Letter] From Thomas H. Barker to William Lloyd Garrison. Manchester, Mar. 7, 1865.

BLAINE, James G.; GARFIELD, James A.; BLAIR, Montgomery; LAMAR, L. Q. C.; STEPHENS, Alexander H.; HENDRICKS, Thomas A.; HAMPTON, Wade; PHILLIPS, Wendell. Ought the Negro to Be Disfranchised? Ought He to Have Been Enfranchised? The North American Review, [s. l.], v. 128, n. 268, p. 225-283, 1879.

CHAMPION, Judah. Christian and Civil Liberty Considered and Recommended: A Sermon, Delivered Before the General Assembly of the Colony of Connecticut, at Hartford, on the Day of Their Anniversary Election. Hartford: Printed by E. Watson, near the Great-Bridge, May 9th, 1776.

CHANNING, Willian Ellery. Slavery. 3. ed. Boston: J. Munroe, 1835.

CORNELIUS, Janet. 'We Slipped and Learned to Read': Slave Accounts of the Literacy Process, 1830-1865. Phylon, [s. l.], v. 44, n. 3, p. 171-186, 1983.

COX, LaWanda; COX, John H. Negro Suffrage and Republican Politics: The Problem of Motivation in Reconstruction Historiography. The Journal of Southern History, [s. l.], v. 33, n. 3, p. 303-330, 1967.

CRAVEN, Avery. Reconstruction: The Ending of the Civil War. New York: Holt, Rinehart and Winston, 1969.

DAVIS, Henry Winter. On Negro Suffrage. Vermont Watchman \& State Journal, Montpelier, Vermont, July 14, 1865.

DAVIS, Thomas J. Emancipation Rhetoric, Natural Rights, and Revolutionary New England: A Note on Four Black Petitions in Massachusetts, 1773-1777. The New England Quarterly, [s. l.], v. 62, n. 2, p. 248-263, 1989.

DU BOIS, William Edward Burghardt. Black reconstruction. Millwood, NY: Kraus-Thomson Org., 1973.

FELDER, Deborah G. A Bookshelf of Our Own: Works That Changed Women's Lives. New York: Citadel Press, 2005.

FONER, Eric. Reconstruction: America's Unfinished Revolution, 1863 - 1877. New York: Harper Perennial, 1988.

FONER, Philip Sheldon. From Africa to the Emergence of the Cotton Kingdom. Westport, CT: Greenwood Press, 1975.

FRANTZ, Laurent B. Congressional Power to Enforce the Fourteenth Amendment Against Private Acts. The Yale Law Journal, [s. l.], v. 73, i. 8, p. 1353-1384, 1964.

GARRISON, Wendell Phillips. William Lloyd Garrison, 1805-1879: The Story of His Life Told 
by His Children. Boston: Houghton Mifflin, 1889.

GARRISON, William Lloyd. An address delivered before the Old Colony Anti-Slavery Society at South Scituate, Mass., July 4, 1839. Boston: Dow \& Jackson, 1839.

GAZETTE, Virginia. Supplement to Dixon and Hunter, [s. l.], June 8, 1776.

GUTMAN, Herbert G. Black Family in Slavery and Freedom, 1750-1925. New York: Pantheon Books, 1976.

HAMILTON, Alexander. A Full Vindication. In: LODGE, Henry Cabot (ed.). The Works of Alexander Hamilton. V. 1. New York: G. N. Putnam’s sons, 1904 [Original: 1774].

HAMILTON, Alexander. The Farmer Refuted. In: LODGE, Henry Cabot (ed.). The Works of Alexander Hamilton. V. 1. New York: G. N. Putnam’s sons, 1904 [Original: 1775].

HAMMOND, James Henry. Letter to an English Abolitionist. In: FAUST, Dred Gilpin (ed.). The Ideology of Slavery: Proslavery Thought in the Antebellum South, 1830-1860. Baton Rouge: Louisiana State University Press, 1981.

HIGHGATE, Edmonia G. Letter from Edmonia G. Highgate to M. E. Strieby, Dec. 17, 1866. In: STERLING, Dorothy (ed.). We Are Your Sisters: Black Women in the Nineteenth Century. New York: W. W. Norton \& Company, 1984.

HOPKINS, Stephen. The Rights of Colonies Examined. Providence, RI: 1765 [written late 1764].

HUNTER, William. An oration, delivered in Trinity-Church, in Newport, on the Fourth of July, 1801. Newport: Printed at the Office of the Newport Mercury, 1801.

KENDRICK, Benjamin B. The Journal of the Joint Committee of Fifteen on Reconstruction. 39th Congress, 1865-1867. New York: Columbia University Press, 1914.

LINCOLN, William. History of Worcester, Massachusetts, from its earliest settlement to September, 1836. Worcester: Charles Hersey, 1862.

LOCKE, John. The Two Treatises of Government. Cambridge: Cambridge University Press, 1965 [Original: 1690].

MCDOUGLE, Ivan E. The Social Status of the Slave. The Journal of Negro History, [s. l.], v. 3, n. 3, p. 281-302, 1918.

MCPHERSON, Edward. A Political Manual for 1866 [to 1869]. London: Hardpress Publishing, 2012 [Original: 1869].

MELLEN, George W. F. An Argument on the Unconstitutionality of Slavery: Embracing an Abstract of the Proceedings of the National and State Conventions on This Subject. Boston: Saxton \& Peirce, 1841.

MILL, John Stuart. Boston Daily Advertiser, [s. l.], June 8, 1865 [From an excerpt of a letter 
written by John Stuart Mill].

MYERS, John B. The Education of the Alabama Freedmen During Presidential Reconstruction, 1865-1867. The Journal of Negro Education, [s. l.], v. 40, n. 2, p. 163-171, 1971.

NATIONAL WOMAN SUFFRAGE ASSOCIATION. Declaration of the Rights of the Women in the United States. July 4, 1876. In: BUHLE, Mari Jo; BUHLE, Paul. The concise history of Woman Suffrage: Selections from the Classic Work of Stanton, Anthony, Gage, and Harper. Chicago: University of Illinois Press, 1978.

O’NEILL, William L. Everyone Was Brave: A History of Feminism in America. New York: Quadrangle, 1971.

OLCOTT, Charles. Two Lectures on Slavery and Abolition. New York: Books for Libraries Press, 1838.

OSHINSKY, David M. Worse than Slavery. Parchman Farm and the Ordeal of Jim Crow Justice. New York: Free Press Paperbacks, 1996.

PADGETT, James A. From Slavery to Prominence in North Carolina: Preparation. The Journal of Negro History, [s. l.], v. 22, n. 4, p. 433-487, 1937.

PARSONS, Theophilus. Result of the Convention of Delegates holden at Ipswich in the county of Essex, who were deputed to take into consideration the Constitution and form of government, proposed by the convention of the state of Massachusetts-Bay. Newbury-Port, MA: John Mycall, 1778.

PERDUE JR, Charles L.; BARDEN, Thomas E.; PHILLIPS, Robert K. Weevils in the Wheat: Interviews with Virginia Ex-Slaves. Charlottesville: University Press of Virginia, 1976.

PHILLIPS, Wendell. Speech at the American Anti-Slavery Society. National Anti-Slavery Standard, [s. l.], May 13, 1865.

QUINCY, Josiah. Observations on the act of Parliament commonly called the Boston Port-Bill; with thoughts on civil society and standing armies. Boston, MA: Edes \& Gill, 1774.

RAMSAY, David. An oration on the advantages of American independence: delivered before a public assembly of the inhabitants of Charlestown, South-Carolina, on the Fourth of July, 1778, the second anniversary of that glorious aera. Charleston: T.C. Cox, 1778.

RITTER, Gretchen. Jury Service and Women's Citizenship before and after the Nineteenth Amendment. Law and History Review, [s. l.], v. 20, n. 3, p. 479-515, Autumn, 2002.

ROSSITER, Clinton. Seedtime of the Republic. New York: Harcourt, Brace \& World, 1953.

SMALL, Sandra E. The Yankee Schoolmarm in Freedmen's Schools: An Analysis of Attitudes. The Journal of Southern History, [s. l.], v. 45, n. 3, p. 381-402, August 1979.

SPARTANUS. The Interest of America. New-Hampshire Gazette, Portsmouth, June 15, 1776. 
STAMPP, Kenneth M. The Era of Reconstruction, 1865-1877. New York: Alfred A. Knopf, 1969.

STANTON, Elizabeth Cady. Elizabeth Cady Stanton As Revealed in Her Letters, Diary and Reminiscences. Philadelphia: Franklin Press, 2018 [Original: 1865].

STANTON, Elizabeth Cady; ANTHONY, Susan B.; GAGE, Matilda Joslyn. History of Woman Suffrage: 1861-1876. Volume 2. New York: Fowler \& Wells, 1881 [Reprint: 1985].

STEPHENSON, Gilbert T. Racial Distinctions in Southern Law. Am. Pol. Sci. Rev., [s. l.], p. 4461, November 1906.

THE ALARM. New York: Hampden, n. III, October 15th, 1773.

THE EASTERN News: To-day’s Dispatches. Daily Evening Bull. (S.F.), [s. l.], Feb. 25, 1864.

THE GERMAN Radical Convention. Daily Cleveland Herald, [s. l.], Oct. 24, 1863.

THE JOURNAL OF BLACKS IN HIGHER EDUCATION. [s. l.], nº 22, Winter, 1998-1999.

THE WOMAN’S JOURNAL. Boston, v. 10, n. 49, December 6, 1879.

TINDALL, George Brown. America: A Narrative History. New York: W. W. Norton \& Co., 1984.

TSESIS, Alexander. For Liberty and Equality: The Life and Times of the Declaration of Independence. New York: Oxford University Press, 2012.

UNITED STATES OF AMERICA Congressional Documents. Cong. Globe, 42nd Cong., 2nd Sess., December 4, 1871 to June 10, 1872, p. 382-383, 1872. Available at: http://bit.ly/2Hcjnlw. Accessed: 29 Jan. 2020.

UNITED STATES OF AMERICA. Act of Apr. 9, 1866 (Civil Rights Act of 1866). An Act to protect all Persons in the United States in their Civil Rights, and furnish the Means of their Vindication. In: UNITED STATES OF AMERICA. United States Code (Ch. 31, 14 Stat. 27). Washington: Government Printing Office, 1977.

UNITED STATES OF AMERICA. Act of February 5, 1867. Expanding the scope of habeas corpus statutes. In: UNITED STATES OF AMERICA. United States Code (ch. 27, 14 Stat. 385).

Washington: Government Printing Office, 1977.

UNITED STATES OF AMERICA. Act of Mar. 2, 1867 (Peonage Act of 1867). An Act to abolish and forever prohibit the System of Peonage in the Territory of New Mexico and other Parts of the United States. In: UNITED STATES OF AMERICA. United States Code (ch. 187, 14 Stat. 546). Washington: Government Printing Office, 1977.

UNITED STATES OF AMERICA. Act of May 21, 1866 (Slave Kidnaping Act). An Act to prevent and punish Kidnapping. In: UNITED STATES OF AMERICA. United States Code (ch. 86, 14 Stat. 50). Washington: Government Printing Office, 1977. 
UNITED STATES OF AMERICA. Congressional Documents. Cong. Globe, 33d Cong., 1st Sess., December 5, 1853 to August 7, p. 268, 1854. Available at: http://bit.ly/2HdRb1K. Accessed: 29 Jan. 2020.

UNITED STATES OF AMERICA. Congressional Documents. Cong. Globe, 38th Cong., 1st Sess., December 7, 1863 to July 4, 1864, p. 521 (Feb. 8, 1864), 1.199 (Mar. 19, 1864 - Wilson), 1.319 (Mar. 28, 1864), 1.443 (Apr. 6, 1864), 1.488 (Apr. 8, 1864) and 977-1952 (June 15, 1864). Available at: http://bit.ly/2vYnm2D. Accessed: 29 Jan. 2020.

UNITED STATES OF AMERICA. Congressional Documents. Cong. Globe, 38th Cong., 1st Sess., December 7, 1863 to July 4, 1864, p. 1.319 (Mar. 28, 1864). Available at: http://bit.ly/2vYnm2D. Accessed: 29 Jan. 2020.

UNITED STATES OF AMERICA. Congressional Documents. Cong. Globe, 38th Cong., 1st Sess., December 7, 1863 to July 4, 1864, p. 1.324 (Mar. 28, 1864 - Wilson). Available at: http://bit.ly/2vYnm2D. Accessed: 29 Jan. 2020.

UNITED STATES OF AMERICA. Congressional Documents. Cong. Globe, 38th Cong., 1st Sess., December 7, 1863 to July 4, 1864, p. 1.439-1.440 (Apr. 6, 1864). Available at: http://bit.ly/2vYnm2D. Accessed: 29 Jan. 2020.

UNITED STATES OF AMERICA. Congressional Documents. Cong. Globe, 38th Cong., 1st Sess., December 7, 1863 to July 4, 1864, p. 1.461 (Apr. 7, 1864 - Senator John Henderson). Available at: http://bit.ly/2vYnm2D. Accessed: 29 Jan. 2020.

UNITED STATES OF AMERICA. Congressional Documents. Cong. Globe, 38th Cong., 1st Sess., December 7, 1863 to July 4, 1864, p. 2.989 (June 15, 1864). Available at: http://bit.ly/2Syll4V. Accessed: 29 Jan. 2020.

UNITED STATES OF AMERICA. Congressional Documents. Cong. Globe, 38th Cong., 1st Sess., December 7, 1863 to July 4, 1864, p. 2.990 (June 15, 1864 - Representative Ebon Intersoll). Available at: http://bit.ly/2Syll4V. Accessed: 29 Jan. 2020.

UNITED STATES OF AMERICA. Congressional Documents. Cong. Globe, 39th Cong., 1st Sess., December 4, 1865 to July 28, 1866, p. 111 (Dec. 21, 1865). Available at: http://bit.ly/37fV7JC. Accessed: 29 Jan. 2020.

UNITED STATES OF AMERICA. Congressional Documents. Cong. Globe, 39th Cong., 1st Sess., December 4, 1865 to July 28, 1866, p. 1.159 (Mar. 2, 1866 - Representative William Windom). Available at: http://bit.ly/2tHtPhE. Accessed: 29 Jan. 2020.

UNITED STATES OF AMERICA. Congressional Documents. Cong. Globe, 39th Cong., 1st Sess., December 4, 1865 to July 28, 1866, p. 2.079-2.081 (Apr. 21, 1866). Available at: http://bit.ly/2UGCDzm. Accessed: 29 Jan. 2020.

UNITED STATES OF AMERICA. Congressional Documents. Cong. Globe, 39th Cong., 1st Sess., December 4, 1865 to July 28, 1866, p. 2.510 (May 9, 1866). Available at: http://bit.ly/2UGCDzm. Accessed: 29 Jan. 2020. 
UNITED STATES OF AMERICA. Congressional Documents. Cong. Globe, 39th Cong., 1st Sess., December 4, 1865 to July 28, 1866, p. 2.079-2.081 (Apr. 21, 1866). Available at: http://bit.ly/37fVAvm. Accessed: 29 Jan. 2020.

UNITED STATES OF AMERICA. Congressional Documents. Cong. Globe, 39th Cong., 1st Sess., December 4, 1865 to July 28, 1866, p. 3.220 (June 16, 1866). Available at: http://bit.ly/2OIoTAx. Accessed: 29 Jan. 2020.

UNITED STATES OF AMERICA. Congressional Documents. Cong. Globe, 39th Cong., 1st Sess., December 4, 1865 to July 28, 1866, p. 1.063-1.064 (Feb. 27, 1866). Available at: http://bit.ly/2tHtPhE. Accessed: 29 Jan. 2020.

UNITED STATES OF AMERICA. Congressional Documents. Cong. Globe, 39th Cong., 1st Sess., December 4, 1865 to July 28, 1866, p. 1.088 (Feb. 28, 1866 - Woodbridge). Available at: http://bit.ly/2tHtPhE. Accessed: 29 Jan. 2020.

UNITED STATES OF AMERICA. Congressional Documents. Cong. Globe, 39th Cong., 1st Sess., December 4, 1865 to July 28, 1866, p. 1.095 (Feb. 28, 1866 - postponement). Available at: http://bit.ly/2tHtPhE. Accessed: 29 Jan. 2020.

UNITED STATES OF AMERICA. Congressional Documents. Cong. Globe, 39th Cong., 1st Sess., December 4, 1865 to July 28, 1866, p. 133 (Feb. 26, 1866). Available at: http://bit.ly/2tHtPhE. Accessed: 29 Jan. 2020.

UNITED STATES OF AMERICA. Congressional Documents. Cong. Globe, 40th Cong., 3rd Sess., December 7, 1868 to March 3, 1869, p. 863 (Feb. 4, 1869 - Senator Oliver P. Morton). Available at: http://bit.ly/2HdpQg4. Accessed: 29 Jan. 2020.

UNITED STATES OF AMERICA. Congressional Documents. Cong. Globe, 40th Cong., 3rd Sess., December 7, 1868 to March 3, 1869, p. 861-862 (Feb. 4, 1869 - Senator Willard Warner). Available at: http://bit.ly/2HdpQg4. Accessed: 29 Jan. 2020.

UNITED STATES OF AMERICA. Congressional Documents. Cong. Globe, 40th Cong., 3rd Sess., December 7, 1868 to March 3, 1869, p. 1.626-1.627 (Feb. 26, 1869 - Senator Henry Wilson Wilson). Available at: http://bit.ly/3bpGPtn. Accessed: 29 Jan. 2020.

UNITED STATES OF AMERICA. Congressional Documents. Cong. Globe, 41th Cong., 1st Sess., March 4, 1869 to April 10, 1869, p. 72 (Mar. 15, 1869). Available at: http://bit.ly/38gVHZc. Accessed: 29 Jan. 2020.

UNITED STATES OF AMERICA. H.R.J. Res., 15, 41st Cong. 41, Mar. 15, 1869.

UNITED STATES OF AMERICA. Supreme Court of the United States. Blyew v. United States. Opinion: Justice William Strong: Dissent: Justices Noah Swayne and Joseph Bradley. 80 U.S. Reports Volume 581, 1871. Available at: http://bit.ly/39p4Fn8. Accessed: 29 Jan. 2020.

UNITED STATES OF AMERICA. Supreme Court of the United States. City of Boerne v. Flores, 521 U.S. Reports Volume 507; 524. Opinion: Justice William Rehnquist. Dissent: Justice Sandra Day O’Connor, Stephen Breyer, David Souter. 1997. 
UNITED STATES OF AMERICA. Supreme Court of the United States. Morrison v. United States, 529 U.S. Reports Volume 598; 602. Opinion: Justice William Rehnquist. Dissent: Justice Stephen Breyer, David Souter, Ruth Bader Ginsburg, John P. Stevens. 2000.

UNITED STATES OF AMERICA. Supreme Court of the United States. U.S. Reports Volume 521; October Term, 1996; City of Boerne v. P.F. Flores, Archbishop of San Antonio et al. 521 U.S. 507, 520, 532. 1997.

UNITED STATES OF AMERICA. Supreme Court of the United States. United States v. Rhodes, 27 F. C. Reports Volume 785, 786, 793-794. 1866.

UNIVERSAL Emancipation. The Liberator, Boston, v. XXXIV, n 19, May 6, 1864. Available at: http://bit.ly/2SdlTOK. Accessed: 29 Jan. 2020.

VAUGHN, William Preston. Schools for All: The Blacks \& Public Education in the South, 18651877. Lexington, KY: University Press of Kentucky, 1974.

VINDEX. Boston Gazette \& Country Journal, Boston, MA, Jan. 21, 1771.

WELD, Theodore Dwight; BADGLEY, C. American Slavery as it was in 1839. Canal Winchester, OH: Badgley Publishing Company, 2013.

WOLLSTONECRAFT, Mary. A Vindication of the Rights of Woman. Speech at the Massachusetts Historical Society. Boston: Peter Edes for Thomas and Andrews, 1792. University Chicago School of Law. General Editor at the Cambridge Studies on Civil Rights and Civil Liberties.E-mail: atsesis@luc.edu 